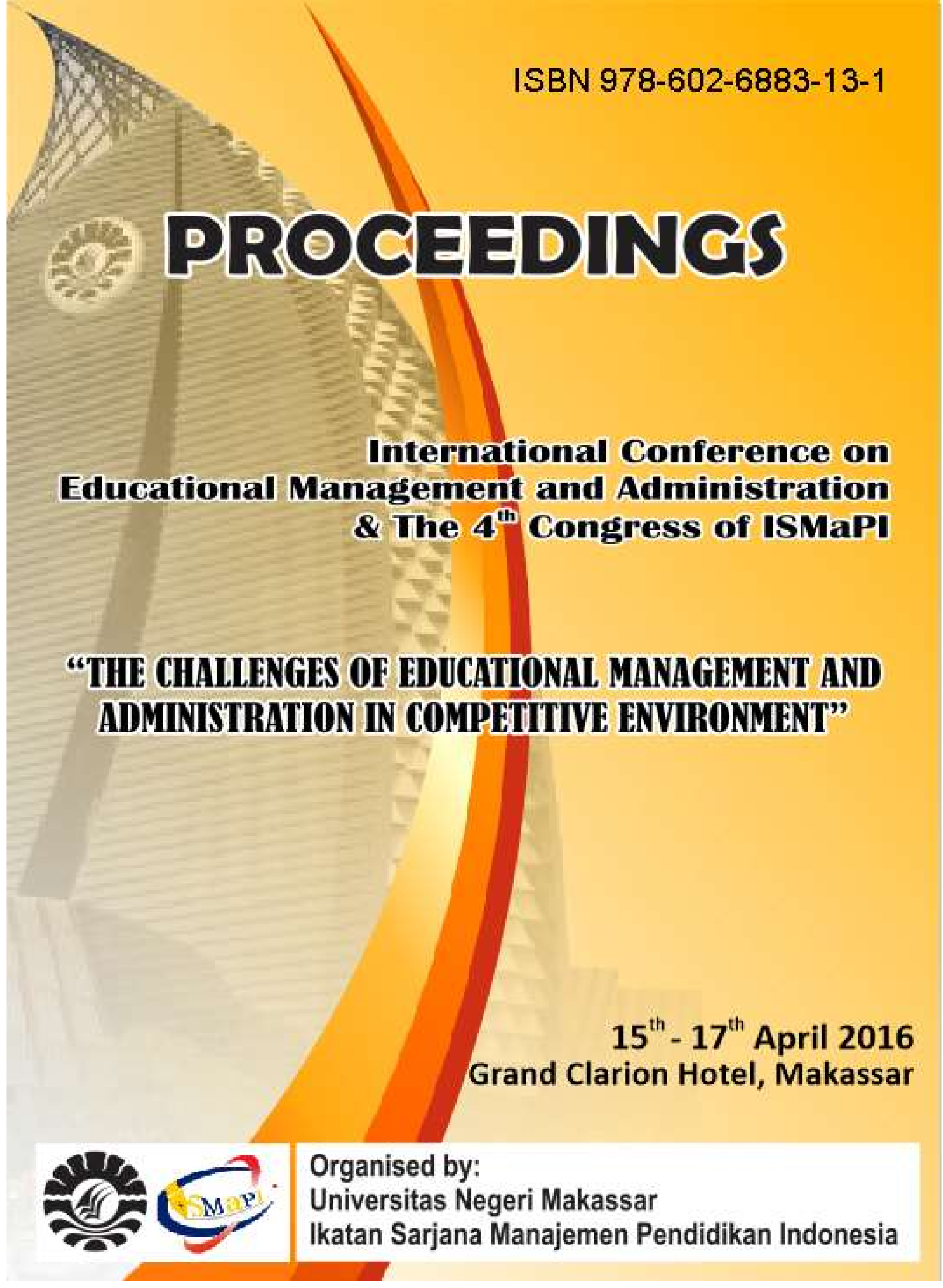




\section{PROCEEDINGS}

\section{International Conference on Educational Management and Administration $\&$ the $4^{\text {th }}$ Congress of ISMAPI}

"The Challenges of Educational Management And Administration in Competitive Environment"

Editor:

Dr. Ed. Faridah, ST. M. Sc

Burhanuddin, M.Ed, Ph.D

Dr. Hadiyanto, M.Ed

Prof. Dr. Ibrahim Bafadal, M.Pd

Prof. Dr. Ismail Tolla, M.Pd

Prof. Dr. Syamsu A Kamaruddin M.Si

Dr. Ratwamati, M.Pd

Dr. A. Cudai Nur, M.Si

Dr. A. Nurrochmah, M.Pd

Dr. Ansar, M.Si

Dr. Wahira, M.Pd. 
International Conference on Educational Management and Administration $\&$ the $4^{\text {th }}$ Congress of ISMAPI

Copy Right @ 2016 by Faridah

Copy right is protected by law

First Edition, 2016

Published by Penerbit Universitas Negeri Makassar

Hotel La Macca Lt. 1 Kampus UNM Gunungsari Baru

J1. A. P. Pettarani Makassar 90222

Tlp./Fax. (0411) 855199

Member of IKAPI No. 011/SSL/2010

Member of APPTI No. 010/APPTI/TA/2011

Reproduction of this book is prohibited without written permission from the Publisher

\section{Faridah}

International Conference on Educational Management and Administrational \& the $4^{\text {th }}$ Congress of ISMAPI/Faridah-cet.1

Makassar: Badan Penerbit Universitas Negeri Makassar

Makassar, 2016

$758 \mathrm{hlm} ; 29,7 \mathrm{~cm}$

ISBN: 978-602-6883-13-1 


\title{
PRINCIPAL INSTRUCTIONAL LEADERSHIP FOR IMPROVED STUDENT ACHIEVEMENT
}

\author{
Ahmad Sabandi \\ Universitas Negeri Padang, Kampus UNP Air Tawar, Padang, Indonesia \\ Email: andi_tendik@yahoo.com
}

\begin{abstract}
School leadership factor is an important factor in determining the success of education. Some phenomena show that the role of the school principal indicated unsatisfactory. This is due, still low mastery of competencies principal. In addition, Indonesian student achievement in international areas still indicated a lower category. The purpose of this paper is to describe the principal's leadership influence learning on the success of student learning. This paper is based on relevant literature review covering both conceptual and research. Based on the results of a literature review, there are three dimensions of instructional leadership and each contained subdimensions, such as: defines the school mission: frames the school goals, communicates the school goals; manages the instructional program: supervises and evaluates instruction, coordinates curriculum, and monitors student progress; and to develop a positive school learning climate: protects instructional time, maintains high visibility, provides incentives for teachers, promotes professional development, and provides incentives for learning. The results of the study of instructional leadership principals indicate that the higher the average level of the leadership of higher learning achievement levels of students. The implication of these studies is to increase student achievement can be done through increasing instructional leadership principals.
\end{abstract}

Keywords: instructional leadership, leadership in education, school leardership, principal school, student achievement 


\section{A. Background}

The role of education in national development is very strategic. Nation building requires human resources that are reliable, able to think and act strategically in order to be able to face the challenges of global development. Resource is people who will determine what strategic actions to be performed, allocating more resources, and coordinate all the resources to play an optimal role and synergize with each other. In addition, human resources also determine the extent of the success achieved and find solutions to any obstacles encountered. Human resources thus, can only be formed through an educational role.

As an important component in the development of the nation's human resource development is absolutely necessary in order to meet the development needs of the nation. The human resource development through education. Education is a means to establish a human resources in order to develop optimally both from the psychological and pisiknya conducted through an institution as well as individuals.

One important component of the educational institutions that hold is the principal; who is the leader, directing and coordinating all personnel and resources to function optimally function of the success of the school in education. Various other components of the educational institutions are teachers, facilities and infrastructure, school personnel, students, curriculum, community leaders, parents, and government. All of these components need to be coordinated so that each function optimally so that it can contribute optimally to the achievement of educational goals.

The importance of the principals set forth in the policies of the government. Regulation of the Menteri Negara Pendayagunaan Aparatur Negara dan Reformasi Birokrasi No. 16 of 2009 on Jabatan Fungsional Guru dan Angka Kreditnya in Article 13 paragraph (4), stated that "the principal as educators is part educational leader". In addition, the Government Regulation No. 19 Year 2005 on Education National Standar; elucidation of Article 51
Paragraph (1), stated that "the leadership of the education unit consists of school/madrasah principal and vice-principal." Furthermore, the principal as educational staff duties as stated in Republic Act number 20 of 2003 on National Education System Article 39 Paragraph (1), that "education personnel in charge of the administration, management, development, monitoring, and technical services to support the educational process in the educational institution." Liability head school, as stated in Republic Act number 20 of 2003 on National Education System Article 40 Paragraph (2), namely; "Create an atmosphere of meaningful education, fun, creative, dynamic, and dialogue, committed professionally to improve the quality of education, and exemplify and maintain the good name of the institution, profession, and position in accordance with the trust given to him."

So important is the role of the school principal, demanding that the principal should be able to perform their duties optimally. An overview of the performance of today's principals indicated unsatisfactory. As disclosed Gultom (Kompas, 2012) that "the performance of principals in kindergarten and high school/vocational schools in various regions since regional autonomy rated unsatisfactory". The low performance of the principal of which is determined by the competence of the headmaster. As noted Siswandari (Kompas, 2012), that "in fact, the competence of headmasters of concern". Furthermore, Siswandari (Kompas, 2012) argued that "based on competency mapping principals in 31 provinces, found that the lower social competence and supervision ... competence of principals generally still below the minimum threshold of graduation".

On the other hand, the image quality of education, it appears from the results UNAS last few years, in the year 2010 as many as 35 567 students or $6.66 \%$ junior secondary schools in East Java and 1,600 or $20 \%$ of students in Balikpapan City do not pass the national exam (Suara Mardeka, September 15 2014). Studies conducted by PISA to students aged 15 years in the subjects of reading is $39^{\text {th }}$ in $2000,39^{\text {th }}$ in $2003,48^{\text {th }}$ in 2006 , and $57^{\text {th }}$ in 2009; the subjects of mathematics is $39^{\text {th }}$ in 
$2000,38^{\text {th }}$ in $2003,50^{\text {th }}$ in 2006 and $61^{\text {th }}$ in 2009 ; and science subjects is $38^{\text {th }}$ in $2000,38^{\text {th }}$ in $2003,50^{\text {th }}$ in 2006 and $60^{\text {th }}$ in 2009 . The number of participants in 2000 as many as 41 countries, in 2003 as many as 40 countries, in 2006 as many as 56 countries to read and 57 countries for mathematics and science, and in 2009 as many as 65 . the results of the PISA study showed that Indonesia ranked in the subjects of reading, mathematics and science tend to decrease. This data illustrates that the quality of education in Indonesia, in addition to showing less than satisfactory ratings, also tend to decrease.

Based on the above, that the principal's role as a leader of the education needs to be improved. One effort to improve the role of school principals in leadership education is through increasing the role of the principal as instructional leadership. In this regard, the objective of this paper is to describe the influence of instructional leadership of principals on student achievement. The approach taken to meet these goals is based on a literature review related to covering conceptual and research.

\section{B. Understanding Instructional Leadership}

The concept of thought leadership in the opinion of expert opinion is more focused on efforts to increase student achievement. Sim $(2011,1784)$ suggested that the instructional leadership refers to leadership is directly related to the learning process, including the interaction between teachers, students, and curriculum. Sergiovanni, as quoted Sim $(2011$; 17841785), that instructional leadership refers to the ability to develop the teaching program, which includes the ability to interpret the curriculum and determine the learning objectives, the variety of learning methods, managing a classroom, creating a climate of learning, learning innovations, as well as influencing and coordinating teachers and students to achieve educational goals in school.

Furthermore, Horng and Loeb $(2010 ; 69)$ reveals that strong instructional leadership is very important for schools to be successful. However, the narrowly defined only in terms of curriculum and learning in the classroom, instructional leadership may not result in increased student learning or other desired outcomes. School leadership can affect students' learning when supported by effective teaching and learning environment. In other words, learning leadership as improving the quality of learning in order to meet education goals not only narrowly construed increase learning in the classroom, but more broadly due to an increase in the supporting factors and support effective teaching and learning environments to generate increased student learning

\section{Learning Leadership Functions}

Among the benefits of learning leadership is as stated by Stronge, Richard and Catano (2008: 4), namely: building and maintaining the school's vision, shared leadership, leading the learning community, using the data to make instructional decisions, and monitoring of curriculum and instruction. Vision is an agreement on a course of action the behavior of every citizen of the school. Given this vision, all the energy and resources and is directed at the agreed vision. Therefore, it is important for principals maintain vision to all members of the school. In addition, the principal as instructional leadership role also influence each school community to act and participate invite other school communities in achieving the school's vision to utilize all the potential and participate in monitoring the success of school programs and find solutions when facing obstacles.

\section{Learning Leadership Influence on Student Achievement}

Leadership learning effect on student achievement. Andrew Studies (Sim, 2011; 1785) found that the instructional leadership of school principals positively correlated with student achievement in school exams. Furthermore, Wang et.al (Sim, 2011; 1785) found that factors that include leadership 
learning school principals, classroom management, quality of teaching, classroom climate, teacher-student interaction and peer influence toward greater student achievement. Hallinger (2005:3-4) states that the leader is seen as the builder of cultural learning through an academic press that sets high expectations and standards for students and teachers. In addition, leaders are goal-oriented learning, whose main focus is to increase students' academic results.

Furthermore, Hammond (2011:1) states that although there are differences of opinion about the most effective ways to assess and develop its effectiveness; educators and policy makers generally agree that it was done with the ability of teachers increase student learning - and that school leaders can help teachers do the most significant step to improve student achievement. In other words, that the effectiveness of learning can be seen from student achievement. Therefore, teachers should be able to carry this out is to improve student achievement; while the leader of the school is to help teachers to be able to implement an increase in student achievement. Thus thought instructional leadership focused on improving student achievement by helping and providing an enabling environment so that teachers can do their job effectively.

Instructional leadership effect on student achievement through improved conditions directly related to student learning. It is, as the result of a study conducted by Louis (2010: 67) for six years on the leadership of the school is coordinated by the Wallace Foundation, that school leaders primarily affects student learning by influencing motivation and working conditions of teachers. Furthermore, the study results Setwong (2013:2861) found that the effectiveness of school leadership affects learning. Professional development is a proven cause variable has the highest influence on the effectiveness of the school, either directly or indirectly. The indirect effect occurs through curriculum development and learning and the creation of learning climate. Professional development show had the highest total effect because the planning for the development and promotion of professional advancement, promotion of research and promotion actions lifelong learning for teachers had a positive impact on the effectiveness of school-student achievement. Professional development is a systematic approach that will change the system of learning based on the beliefs and attitudes of teachers towards learning.

One form of professional development is supervision carried out by the principal. Studies conducted by Wolfrom (Setwong, 2013:2861) showed that the supervision conducted by school administrators can demonstrate more clearly the needs of teachers and can improve professional development. This, supported by a study conducted by Cohen \& Hill, Ferguson, Rosenholtz, and Wenglinski (Setwong, 2013:2861) cited by that students are taught by teachers who have been trained professionals reaching more than students taught by teachers who have not been trained in the profession.

Based on the description above can be concluded instructional leadership influences student achievement through the creation of an environment that allows learning activities take place effectively. These activities can be done through the professional development of teachers, improving learning facilities and infrastructure, the development of effective curriculum and learning environment a pleasant atmosphere.

\section{E. Dimensions and Research Leadership Learning}

Description previously been disclosed that the functioning of the principal as instructional leadership very well have an impact on student achievement through the professionalism of teachers and the creation of conditions conducive learning environment activities. Furthermore, the disclosed dimensions of instructional leadership is based on the opinions of experts. Some models of instructional leadership dimension including the following.

\section{Smith and Andrew (1989)}

Smith and Andrew (1989:9-20) suggested four areas of strategic area between principals and teachers were significantly related to student achievement, namely; 
principals as a resource provider, the principal source of learning, the school principal as a communicator, and the principal as visible presence. As a resource provider, the principal of leverage and increase the professionalism of school personnel, providing infrastructures, budgets for learning, information systems to involve the participation of staff in decisionmaking, the literature to support the learning, organizational structure more flexible. Strong learning leader is a leader who has the ability to mobilize resources to implement policies that lead to the expected results. As a source of learning, principals are actively involved in classroom improvements that enhance learning, encourage the use of a variety of teaching materials and teaching strategies, resources and creativity of teachers keinovatifan, facilitate learning fun. Effective school principals deemed able to allocate resources to maximize teacher effectiveness and student success. Although the principal may not have any special knowledge of the subjects taught in schools, at least should have knowledge of the general trend in each subject. Effective school head must have sufficient knowledge to understand and evaluate innovative curricular, teaching methods and principles of effective learning. As a communicator, the principal role of articulating the vision of the school that will lead everyone in the same direction. The school principal use communication as a basis for developing relations between staff through conduct consistent, objective and useful directed on a commitment to academic purposes. As a visible presence, principals interacted with the staff and students in the classroom and hallways, attending meetings and departmental grade level, and have a conversation with the teacher. The presence of the school principal felt throughout the school as a guard vision. Principals who are constantly visible displays behaviors that reinforce the values of the school. The school principal know as the first to move the school every day. The headmaster shows the values to protect schools from other interests. The presence of the school principal felt in formal and informal observations for classroom teachers. After being out and about, principals expressed appreciation verbally and through written records informally. Teachers regard, principals visible presence if frequent classroom observations, easily accessible to discuss matters related to learning, regularly being around the classroom building, and actively participate in staff development activities.

\section{Dimensions Robinson, Lloyd, and Rowe (2008)}

Robinson, Lloyd, and Rowe develop five dimensions of leadership that influence student learning, as the table below.

Table 1. Five Dimensions of Leadership to Student Achievement

\begin{tabular}{|c|c|}
\hline Leadership Dimension & Meaning of Dimension \\
\hline $\begin{array}{l}\text { Establishing goals and } \\
\text { expectations }\end{array}$ & $\begin{array}{l}\text { Includes the setting, } \\
\text { communicating, and monitoring } \\
\text { of learning goals, standards, and } \\
\text { expectations, and the involvement } \\
\text { of staff and others in the process } \\
\text { so that there is clarity and } \\
\text { consensus about goals. }\end{array}$ \\
\hline Strategic resourcing & $\begin{array}{l}\text { Involves aligning resource } \\
\text { selection and allocation to priority } \\
\text { teaching goals. Includes provision } \\
\text { of appropriate expertise through } \\
\text { staff recruitment. }\end{array}$ \\
\hline $\begin{array}{l}\text { Planning, coordinating, } \\
\text { and evaluating teaching } \\
\text { and the curriculum }\end{array}$ & $\begin{array}{l}\text { Direct involvement in the support } \\
\text { and evaluation of teaching through } \\
\text { regular classroom visits and } \\
\text { provision of formative and } \\
\text { summative feedback to teachers. } \\
\text { Direct oversight of curriculum } \\
\text { through schoolwide coordination } \\
\text { across classes and year levels and } \\
\text { alignment to school goals. }\end{array}$ \\
\hline $\begin{array}{lr}\text { Promoting } & \text { and } \\
\text { participating in teacher } \\
\text { learning } & \text { and } \\
\text { development } & \end{array}$ & $\begin{array}{l}\text { Leadership that not only promotes } \\
\text { but directly participates with } \\
\text { teachers in formal or informal } \\
\text { professional learning. }\end{array}$ \\
\hline $\begin{array}{l}\text { Ensuring an orderly and } \\
\text { supportive environment }\end{array}$ & $\begin{array}{l}\text { Protecting time for teaching and } \\
\text { learning by reducing external } \\
\text { pressures and interruptions and } \\
\text { establishing an orderly and } \\
\text { supportive environment both } \\
\text { inside and outside classrooms. }\end{array}$ \\
\hline
\end{tabular}

Source: Robinson, Lloyd, and Rowe (2008:656)

Robinson, Lloyd, and Rowe formulated five dimensions of instructional leadership, namely: establishing goals and expectations, strategic resourcing, planning, coordination, and evaluating of teaching and 
curriculum, promoting and participating in teacher learning and development, and ensuring an orderly and supportive environment. Dimensional model of instructional leadership by Robinson, Lloyd, and Rowe has been implemented in the form of research. Research results Robinson, Lloyd, and Rowe to various learning leadership approach to student learning outcomes, as shown below.

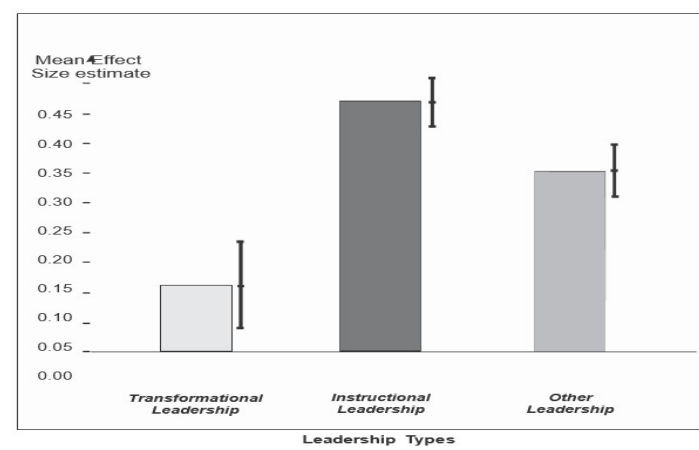

Figure 1. Effect Size average Impact of Transformational Leadership (13 effects of five studies), Leadership Learning (188 effects of 12 studies), and Other Leadership Approach (50 effects of five studies) to the Student Achievement (Robinson, Lloyd, and Rowe 2008: 657)

The image above shows the difference in the average effect size large enough between the three types of leadership. It is, first; confirms the benefits of analyzing the impact of the kind of leadership than the leadership in general, the second is that the estimate of effect size average for instructional leadership impact on student learning outcomes is three to four times greater than transformational leadership. Thus, instructional leadership has a greater effect on student achievement than other leadership approaches.

\section{Dimensions Blase \& Blase (2000)}

Blase and Blase (2000:132-137) suggests two main themes dimensions of instructional leadership, which talking with teachers to promote reflection and promoting professional growth. Each main theme elaborated on several subthemes, as follows: (1) talking with teachers to promote the reflection, which consists of sub-themes: making suggestions, giving feedback, modeling, using inquiry and soliciting advice and opinions and giving praise; and (2) promoting professional growth, which consists of sub-themes: emphasizing the study of teaching and learning, supporting collaborative effort among educators, developing coaching relationships among educators, encouraging and supporting the redesign of programs, applying the principles of adult learning, growth, and development to all phases of the staff development; and implementing action research to inform instructional decision making. Dimensional model of instructional leadership by Blase and Blase has been implemented in the form of research. Results of research Blase and Blase (2000: 137) concluded that talking with teachers to promote the reflection and promoting professional growth are the two main dimensions of leadership for effective learning. Overall, the data indicate that each of the instructional leadership strategies have improvement to the effects, emotional, cognitive, and behavioral strong teachers. Thus, Blase and Blase research proves that instructional leadership has a strong influence on the behavior of teachers, which in the end leads to increased student achievement.

\section{Dimensions Sim (2011)}

Sim develop leadership dimensional model of learning, as the integration of a wide range of expert opinion. Sim $(2011$; 17881789) suggested the instructional leadership model related to the academic performance of student achievement, namely through direct strategy and indirect strategy. Direct strategy is the behavior of the principal in advising and teaching that directly contribute to student learning. While the indirect strategy consists of domain thought leadership that explains the mission, vision and objectives of the school, managing curriculum and instruction, supervision of teaching and learning, monitor student progress, pushing the climate process of learning, improving professional development and collaborate with external parties used by the principal to achieve student achievement. This conceptual framework shows that learning leadership can affect students' academic performance by using 
seven domains of instructional leadership. Instructional leadership model according to Sim, as the following figure.

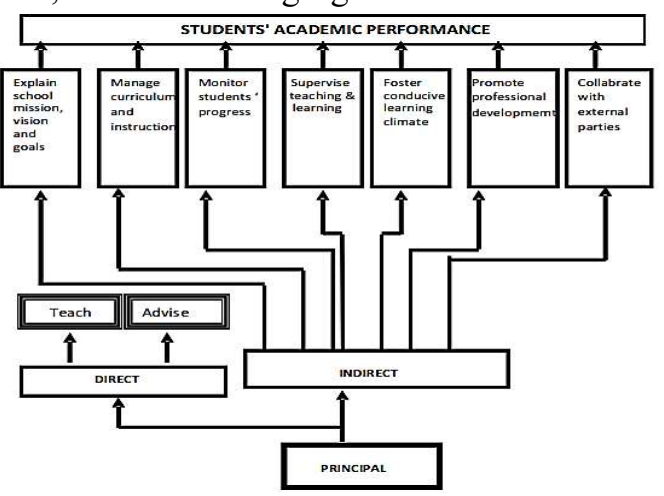

Figure 2. Learning Leadership Model Sim (Sim, 2011:1789)

Dimensional model of instructional leadership by Sim has been implemented in the form of research. Sim (2011:1796) revealed research findings that the principal Malaysia successfully implement all seven dimensions of learning leadership role; namely: (1) explain school mission, vision, and goals, (2) manage curriculum and instruction, (3) supervise teaching and learning, (4) monitor students progress, (5) foster conducive learning climate, (6) promote professional development, (7) collaborate with external parties. In particular, the principal Malaysia has a tendency to use the four dimensions of instructional leadership role, namely; explains the mission, vision and goals of the school, monitoring student progress, foster conducive learning climate and professional development. Sim research results as the following figure.

\begin{tabular}{|c|c|c|c|c|}
\hline Secondary Schools In Johor, Malaysia & $\begin{array}{l}\text { Mean } \\
\text { Level } \\
\text { of IL }\end{array}$ & $\begin{array}{l}\text { Level Of IL } \\
\text { Implementatio } \\
n\end{array}$ & $\begin{array}{l}\text { Percentage } \\
\text { of Academic } \\
\text { Performance } \\
\text { (Malaysian } \\
\text { Certificate of } \\
\text { Education } \\
\text { Examination) }\end{array}$ & $\begin{array}{l}\text { Level of } \\
\text { Academit } \\
\text { Achieven } \\
\mathrm{nt}\end{array}$ \\
\hline $\begin{array}{l}\text { SMKTK (High School) } \\
\text { SMSU (ST }\end{array}$ & $\begin{array}{l}4.10 \\
4.04\end{array}$ & $\begin{array}{l}\text { Success } \\
\text { Success }\end{array}$ & $100 \%$ & Excellent \\
\hline SMAJ (Religious School) & $\begin{array}{l}4.04 \\
4.05\end{array}$ & Success & $100 \%$ & $\begin{array}{l}\text { Excellont } \\
\text { Excellent }\end{array}$ \\
\hline SMT (Technique Schoc & 4.00 & & $100 \%$ & Excellent \\
\hline SMKCC (Miss & 4.00 & Suc & $93.1 \%$ & Excellent \\
\hline y School) & 3.5 & Succ & $83.1 \%$ & Good \\
\hline SMK & 3. & Succ & & Good \\
\hline SMK & 3.8 & Suc & $82.2 \%$ & Good \\
\hline SMKSI & 3.8 & Succ & $74.6 \%$ & Satisfacte \\
\hline SMKJI & 3.7 & Success & & Satisfacte \\
\hline SMKTAB (Normal Secondary So & 3.47 & $\begin{array}{l}\text { Moderate } \\
\text { Success }\end{array}$ & $75.0 \%$ & \\
\hline
\end{tabular}

Figure 4. Impact on Student Achievement Leadership Learning (Smp, 2011; 1795)
Based on the picture above, shows that the higher the average level instructional leadership the higher the level of achievement of students.

\section{Dimensions Hallinger and Wang (2015)}

Hallinger and Wang $(2015 ; 27)$ suggested three dimensions instructional leadership, namely: defining the school mission, managing the instructional programs, and developing school learning climate. Hallinger and Wang instructional leadership model as the following figure.
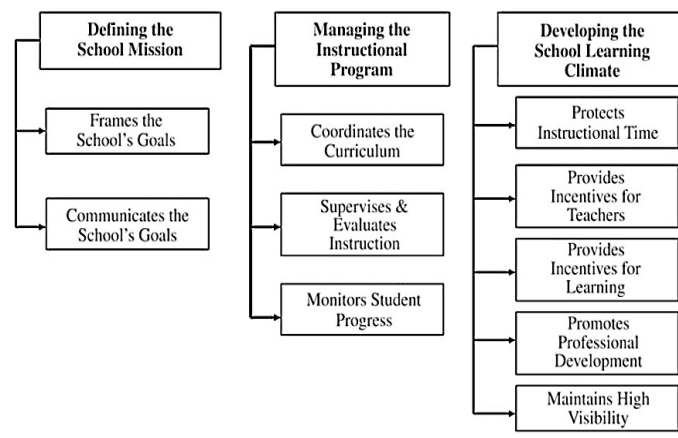

Figure 5. PIMRS Conceptual Framework (Hallinger and Wang, 2015:28)

Hallinger and Wang in the opinion that there are three main dimensions and 10 function in instructional leadership, namely: (1) defining the dimensions the school mission, with the function of frames the school's goals, and communicates the school's goals, (2) the dimensions of managing the instructional programs, with a function; coordinates curriculum, supervises and evaluates instruction, and monitors student progress, and (3) developing school learning climate, with the function of protects instructional time, provides incentives for teachers, provides incentives for learning, promotes professional development, and maintains high visibility.

Dimensional concept of leadership learning developed by Hallinger and Wang can be explained that: (1) The dimensions define the mission of the school is supported by a study conducted by Robinson et al (Hallinger, 2015 ; 27) that puts the vision and goals as the second factor most significantly where principals contribute to improve learning in the 
classroom; vision refers to a comprehensive overview of the direction in which the school tried to move, while the objective refers to specific targets to be achieved on the way towards that vision; (2) the dimensions of managing learning programs, that are widely principals are not only involved in monitoring and developing learning programs in schools, but also to coordinate and control the academic program as a key accountability of school leadership although the task is delegated to other school personnel; (3) develop a positive learning climate of the school, where the principal prepare teachers can do the job more efficiently and effectively which is also called up the structure and process of designing academic or organizations; in the school culture, this structure can form expectations, norms, the school's capacity for change.

Based on the description above, that there are various models of the dimension of instructional leadership. Each model was developed based on the review of the literature; among others is already implemented in the form of research. Results of studies have proven that instructional leadership influence on student achievement. Compared with some of the leadership approach, that instructional leadership have a higher impact on student achievement.

\section{E. CONCLUSION}

Based on the above review of the literature shows that instructional leadership effect on student achievement, both directly and indirectly. Directly conducted through advisory services and teaching principals; while indirectly done through maintaining the school's vision, improving the professionalism of teachers, provision of learning facilities were adequate, providing conditions conducive to the teachers and students for learning activities, as well as the principal coordination in the implementation of programs and solutions when school communities face obstacles.

\section{REFERENSI}

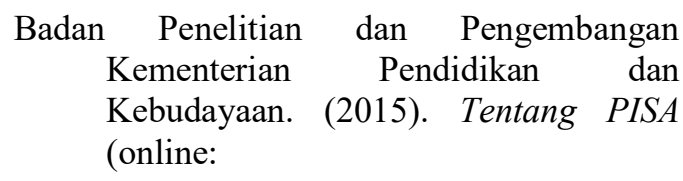

http://litbang.kemdikbud.go.id/index.ph $\mathrm{p}$ /survei-internasional-pisa, diakses pada Januari 2015)

Eileen Horng dan Susanna Loeb. (2010). New Thinking About Instructional Leadership. Kappanmagazine.org. V92 N3 p. 69

Hallinger, Philip, Wen-Chung Wang. (2015). Assessing Instructional Leadership with the Principal Instructional Management Rating Scale. Switzerland: Springer International Publishing

Hallinger, Phillip. (2005). Instructional Leadership and the School Principal: A Passing Fancy That Refuses to Fade Away. Leadership and Policy in Schools 4, no. 3: 1-20.

Hammond, Linda Darling and Robert Rothman. (2011). Teacher and Leader Effectiveness in High-Performing Education Systems. Washington, DC: Alliance for Excellent Education and Stanford Center for Opportunity Policy in Education

Louis, Karen S., Kenneth Leithwood, Kyla L. Wahlstrom, and Stephen E. Anderson. (2010). Investigating the Links to Improved Student Learning. Final Report to the Wallace Foundation, Center for Applied Research and Educational Improvement, University of Minnesota and Ontario Institute for Studies in Education, University of Toronto.

Robinson, Viviane M. J., Claire A. Lloyd, and Kenneth J. Rowe. (2008). The Impact of Leadership on Student Outcomes: An Analysis of the Differential Effects of Leadership Types. Educational Administration Quarterly Vol. 44, No. 5: 635-674

Setwong, Rittirong, Thanomwan Prasertcharoensuk. (2013). The Influence of Instructional Leadership of School Administrators on School Effectiveness. Procedia - Social and Behavioral Sciences 106: 2859 - 2865. 
Sim, Quah Cheng. (2011). Instructional leadership among principals of secondary schools in Malaysia. Educational Research (ISSN: 21415161) Vol. 2(12) pp. 1784-1800.

Stronge, James H., Holly B. Richard, and Nancy Catano. (2008). Qualities of effective principals. Alexandria, Virginia USA: Association for Supervision and Curriculum Development.

Suara Mardeka. (2014). Prestasi Belajar Matematika Siswa Indonesia Sangat Rendah (online: http://berita.suaramerdeka.com/prestasi -belajar-matematika-siswa-indonesiasangat-rendah/, diakses pada15 September 2014) 